\title{
Rевевки Автіск: : Background profile of S.H.G. members of Jorhat district of Assam
}

Dhruba Jyoti Mudoi, Sayanika Borah and Manju Dutta Das

Article Chronicle:

Received :

25.08.2020;

Revised:

16.09.2020;

Accepted :

03.10 .2020

\section{KeY Words :}

Self-help group, Profile characteristics, Empowerment of women
SUMMARY : A self-help group ( $\mathrm{SHG}$ ) is a voluntarily association of people with common goal. The concept of "self-help groups appears to be a good substitute strategy to involve people in the improvement process. Empowerment of women through self-help groups has benefited not only the individual women but also her family and community as a whole. The study was carried out in the Jorhat district of Assam. Four blocks were selected from national rural livelihood mission (NRLM) initiative blocks. Thus, all total 16 self-help groups were selected from these blocks for the present study. Ten members from 16 SHG's, total 160 members were selected using simple random sampling for the study. Majority of 54.4 per cent of the members belonged to young aged category i.e. 27 - 39 years. A large majority ( $95.00 \%$ ) of the respondents were married and 37.50 per cent of the respondents had education upto high school level. A majority of the respondents $(56.30 \%)$ belonged to the OBC category, 68.10 per cent belonged to nuclear family and 62.50 per cent belonged to small family size. Majority of the respondents ( $48.8 \%$ ) were marginal i.e. having 3-7.5 bigha of land holdings. Majority of the respondent's family occupation $(41.70 \%$ ) was cultivation and 56.30 per cent had medium income level and 91.00 per cent were member of one organization. Majority of the respondents $(91.25 \%)$ possessed television and 40.00 per cent attended training programme during the year 2017, 91.87 per cent source of information were extension officers, 88.75 per cent had contact with community resource person. A high percentage ( $62.50 \%$ ) of members of self-help group were completely dependent on bank namely Gramin Vikash Bank for their entrepreneurship development.

How to cite this article : Mudoi, Dhruba Jyoti, Borah, Sayanika and Das, Manju Dutta (2020). Background profile of S.H.G members of Jorhat district of Assam. Agric. Update, 15(4): 282-288; DOI : 10.15740/HAS/AU/ 15.4/282-288. Copyright@ 2020: Hind Agri-Horticultural Society.
Author for correspondence :

\section{Dhruba Jyoti Mudoi}

Department of Extension and Communication

Management, College of Community Science, Assam Agricultural University, Jorhat (Assam) India

Email: dhrubajyotimudoi (a) gmail.com

See end of the article for authors' affiliations 